\title{
A KATONAI LOGISZTIKA ALAPKÉPZÉSI SZAK PÁNCÉLOS ÉS GÉPJÁRMÜTECHNIKAI MODULJÁN VÉGZETT HALLGATÓK TANULMÁNYI EREDMÉNYEI ÖSSZEHASONLÍTVA A KORÁBBI KÉPZÉSEKKEL
}

\section{COMPARISON OF LEARNING OUTCOMES OF MILITARY LOGISTIC ARMOUR AND VEHICLES CADETS WITH THE PREVIOUS MAYORS}

\author{
GYARMATI József; VÉG Róbert László \\ (0000-0001-7594-2383); (0000-0002-9786-9702) \\ gyarmati.jozsef@uni-nke.hu; veg.robert@uni-nke.hu
}

\begin{abstract}
Absztrakt
A cikk egy korábbi tanulmány kutatásának a folytatása, ahol a címben megnevezett modul szakmai tartalmának a változása lett megvizsgálva az elmúlt másfél évtized három különböző képzési formájában, Jelen tanulmány azt vizsgálja, hogy a hallgatók milyen minöségben tudták teljesíteni az egyes képzések során a tantárgyak által támasztott követelményeket
\end{abstract}

Kulcsszavak: páncélos és gépjármütechnikai képzés, statisztikai analízis

\begin{abstract}
In this paper we will show the changes of average of grades of the BSc mayor mechanic engineering armour and vehicles sub major cadets with the military engineer armour and vehicles specialization cadets and military logistic armour and vehicles cadets. The comparison was carry out using mathematical statistic methods.
\end{abstract}

Keywords: armored and vehicle engineering training, statistics 


\section{BEVEZETÉS}

Az oktatás, a képzés és ennek kapcsolatrendszere a $\mathrm{K}+\mathrm{F}+\mathrm{I}$ folyamataival rendszeresen kutatott és publikált terület [1], [2], [3], [4], [5], [6]. Az elmúlt másfél évtizedben a honvédtisztképzésnek három különféle rendszere szolgálta a Magyar Honvédség tisztutánpótlását [7], [8], [9]. Fontos tudni, hogy a különböző szakokon keresztül megvalósított oktatás milyen mértékben és minőségben szolgálta a parancsnok és a szaktisztutánpótlást. Esetünkben a szaktisztutánpótlás lett megvizsgálva, támaszkodva korábbi hasonló területtel foglalkozó tanulmányokra és felhasználva azok adatait. A korábbi tanulmányunkban a páncélos és gépjármütechnikai képzés szakmai tartalmának, óraszámainak illetve a területre vonatkozó képzési és kimeneteli követelmények változásával foglalkoztunk [8]. Fontos megállapítás a meghatározó szakmai tantárgyak óraszámainak a tendencia jellegü csökkenése, ami az elmúlt két évtizedben folyamatosan megfigyelhető volt. A kutatómunka egyrészének az összefoglalása az 1. pont ábra, ami grafikusan mutatja az óraszámok csökkenését.

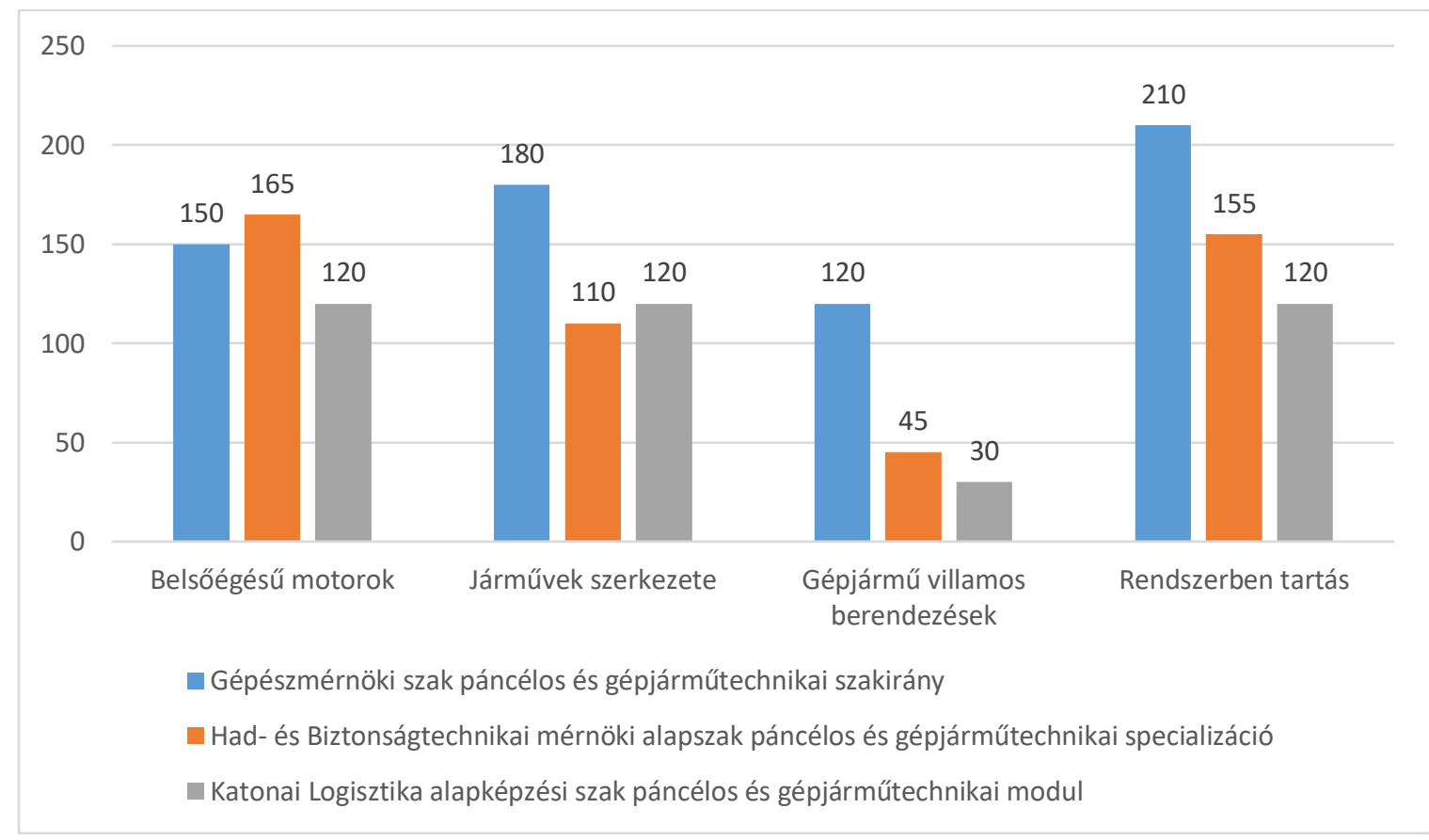

\footnotetext{
1. ábra A fontosabb szakmai tantárgyak óraszámai az elmúlt két évtizedben folytatott képzési formák esetében Forrás: [8]
}

Az ábra alapján látható, hogy legjelentősebb a csökkenés a „Gépjármű villamos berendezések” szakmai területen (75\%) de jelentős tanóra veszteség van a „Rendszerben tartás” szakmai területen is $(43 \%)$. A tanórák számának a csökkenése egyértelmüen maga után vonja a végzett honvédtisztjelöltek szakmai azon belül páncélos és gépjármütechnikai felkészültségének csökkenését is, viszont figyelembe kell venni azt is, hogy az óraszámok változásával egyidejüleg változtak a szakmai felkészültséggel kapcsolatos elvárások is. A vizsgálati célt tehát célszerübb úgy megfogalmazni, hogy milyen mértékben elégítették ki illetve elégítik ki a hallgatók (honvéd tisztjelöltek) a rá vonatkozó követelményeket.

A kutatás módszere a [8] irodalomban felsorolt szakmai területekhez kapcsolódó tantárgyak osztályzatainak statisztikai vizsgálata (hipotézisvizsgálat) volt. A vizsgálat során a nullhipotézisek úgy kerültek felállításra, hogy az esetleges változások például az átlag és a szórás csökkenése illetve növekedése statisztikai szempontból szignifikáns volt vagy sem. Ennek megfelelően egyoldali próbák lettek alkalmazva. 


\section{STATISZTIKAI VIZSGÁLAT}

Az 1. táblázatban felsorolt tantárgyak esetében meg a féléves tanulmányi átlag kétmintás $t$ próba segítségével került megvizsgálásra., vagyis választ lehetett kapni, hogy az elöírt ismeretek elsajátításának minőségében történ-e változás. A kétmintás $t$-próba elvégzéséhez ismerni kell a minták varianciáit, ugyanis más-más $t$-próba tartozik az azonos és az eltérő varianciával rendelkező mintákhoz. A statisztikai függvények értékeinek a változása további információt szolgáltat, hiszen a nagy szórás feltételezi a több gyenge és jobb képességekkel vagy szorgalommal rendelkező hallgatót.

A varianciákat kétmintás F-próba segítségével kerültek ellenőrzésre, ahol a nullhipotézis:

$$
\mathrm{H}_{0}: \sigma^{2}{ }_{1}=\sigma_{2}^{2} \text {, }
$$

az ellenhipotézis:

$$
\mathrm{H}_{1}: \sigma^{2}{ }_{1}>\sigma^{2}{ }_{2} \text {. }
$$

A varianciák rangsora úgy lett felállítva, hogy az $s^{2}{ }_{1}>s^{2}{ }_{2}$ egyenlőtlenség fennálljon. Ennél fogva ellenőrizhető volt, hogy egy nagyobb tapasztalati szórásnégyzet jelenthet-e magasabb varianciát, vagyis a szórásnégyzetek eltérése utalhat-e a varianciák szignifikáns eltérésére.

Az eredményeket a 2. táblázat mutatja. Az egymást követő képzések lettek csak összehasonlítva tehát a gépészmérnök a hadmérnökképzéssel és a hadmérnökképzés a katonai logisztikai képzéssel. A 2. táblázat négy sorban mutatja az elvégzett statisztikai próbákat, mindegyik sor egy adott tantárgycsoporthoz tartozik (Jármüvek szerkezete, Rendszerbenntartás, Belsőégésü motorok, Villamos berendezések). Tantárgyanként két statisztikai próba került alkalmazásra, amelyeket a táblázatban függőleges vastag vonal választ el. A képzési szakok sorrendje nem azonos a $\mathrm{H}_{1}$ ellenhipotézis szórásra vonatkozó feltétele miatt. A szignifikanciaszint a statisztikai gyakorlatban elfogadott $\alpha=0,05$ volt. A próba szignifikanciáját a „, $\mathrm{P}(\mathrm{F}<=\mathrm{f})$ egyszélü" sora mutatja. Amennyiben ez az érték $(p)$ 0,05-nél nagyobb a $\mathrm{H}_{0}$ nullhipotézis kell elfogadni, ha kisebb, akkor a $\mathrm{H}_{1}$ ellenhipotézist. A nullhipotézist elfogadó próbák $p$ értékei kékkel, az ellenhipotézist elfogadó próbák értékei pirossal vannak jelölve a táblázatban.

A táblázatból látható, hogy két esetben lett elutasítva a nullhipotézis a Hadmérnök-Katonai Logisztika viszonylatban a Belsőégésü motorok és a Villamos berendezések tárgyak esetében. A többi esetben a nullhipotézis el lett fogadva, vagyis a varianciák egyformának tekinthetők.

A Belsőégésű motorok és a Villamos berendezések tárgyak esetében viszont kijelenthető, hogy a Katonai logisztikai képzésben ezen tárgyak osztályzatainak szórása csökkent vagyis kevesebb a rossz de sajnos kevesebb a kiemelkedő tanuló is. Az osztályzatok jobban tömörülnek, jóval kevesebb az elégséges és a jeles osztályzat, a hallgatók többsége átlagos.

A varianciák azonosságára vonatkozó statisztikai próbák eredményei segítségével eldönthetővé vált, hogy melyik kétmintás $t$-próba legyen alkalmazva a várható értékek összehasonlítására. A próba célja az volt hogy az osztályzatok alapján eldönthető legyen, hogy a hallgatók (honvéd tisztjelöltek) az egymást követő képzések során azonos mértékben teljesítették a tantárgyakra vonatkozó követelményeket, vagy változás történt. Amennyiben változás történt, vagyis az osztályzatok átlagai a különböző képzési formákban eltérést mutattak, akkor az eltérés mértéke alapján az lett megvizsgálva, hogy annak nagysága alapján kijelethetö-e hogy javulás esetleg romlás történt az elöírt követelmények teljesítése során. Fontos tudni, hogy a képzési követelmények a különböző képzési formákban eltérőek voltak. Ez következeik már az 1. ábra adataiból, ami szerint az egyes tantárgyakra fordítható óraszámok folyamatos csökkenést mutatnak. Ezen felül figyelembe kell venni, hogy a katonai logisztika alapképzési szak nem a müszaki képzési területen akkreditált szak, tehát a müszaki (szakmai) 
tárgyaira vonatkozó követelményei nem a müszaki szak követelményeinek a szintjén lettek meghatározva.

\begin{tabular}{|c|c|c|c|c|}
\hline $\begin{array}{l}\text { Jármúvek } \\
\text { szerkezete }\end{array}$ & Gépészmérnök & Hadmérnök & $\begin{array}{c}\text { Katonai } \\
\text { Logisztika }\end{array}$ & Hadmérnök \\
\hline Átlag & 3,484848485 & 3,458333333 & 3,75 & 3,458333333 \\
\hline Variancia & 1,507575758 & 0,780797101 & 0,866666667 & 0,780797101 \\
\hline Megfigyelések & 33 & 24 & 16 & 24 \\
\hline$d f$ & 32 & 23 & 15 & 23 \\
\hline$F$ & 1,930816283 & & 1,109976798 & \\
\hline$P(F<=f)$ egyszélü & 0,052390304 & & 0,400024811 & \\
\hline F kritikus egyszélü & 1,94909981 & & 2,128217048 & \\
\hline Rendszerbentartás & Gépészmérnök & Hadmérnök & Hadmérnök & Katonai Logisztika \\
\hline Átlag & 4 & 4,444444444 & 4,444444444 & 4,4375 \\
\hline Variancia & 0,896551724 & 0,653968254 & 0,653968254 & 0,529166667 \\
\hline Megfigyelések & 30 & 36 & 36 & 16 \\
\hline$d f$ & 29 & 35 & 35 & 15 \\
\hline $\mathrm{F}$ & 1,370940743 & & 1,235845519 & \\
\hline$P(F<=f)$ egyszélü & 0,18534807 & & 0,339286679 & \\
\hline F kritikus egyszélű & 1,792314311 & & 2,222687283 & \\
\hline $\begin{array}{l}\text { Belsőégésú } \\
\text { motorok }\end{array}$ & Hadmérnök & Gépészmérnök & Hadmérnök & Katonai Logisztika \\
\hline Átlag & 3,958333333 & 4 & 3,958333333 & 4,5625 \\
\hline Variancia & 1,346014493 & 1 & 1,346014493 & 0,2625 \\
\hline Megfigyelések & 24 & 21 & 24 & 16 \\
\hline$d f$ & 23 & 20 & 23 & 15 \\
\hline $\mathrm{F}$ & 1,346014493 & & 5,127674258 & \\
\hline$P(F<=f)$ egyszélü & 0,252828072 & & 0,001006128 & \\
\hline F kritikus egyszélű & 2,091653939 & & 2,296566779 & \\
\hline $\begin{array}{l}\text { Villamos } \\
\text { berendezések }\end{array}$ & Gépészmérnök & Hadmérnök & Hadmérnök & Katonai Logisztika \\
\hline Várható érték & 4,083333333 & 3,833333333 & 3,833333333 & 4 \\
\hline Variancia & 1,174242424 & 1,060606061 & 1,060606061 & 0 \\
\hline Megfigyelések & 12 & 12 & 12 & 8 \\
\hline df & 11 & 11 & 11 & 7 \\
\hline $\mathrm{F}$ & 1,107142857 & & 65535 & \\
\hline$P(F<=f)$ egyszélü & 0,434485744 & & 0 & \\
\hline F kritikus egyszélü & 2,81793047 & & 3,603037269 & \\
\hline
\end{tabular}

1. táblázat

Kétmintás F-próba szórásnégyzetre

A vizsgálat segítségével az mutatható ki, hogy az elvárásoknak milyen mértékben tettek eleget a hallgatók (honvéd tisztjelöltek).

A kétmintás $t$-próba segítségével az lett ellenőrizve, hogy az osztályzatok átlagai alapján a várható értékek azonosnak tekinthetők-e. Az ellenhipotézis az F-próbához hasonlóan lett megfogalmazva, tehát a nullhipotézis elutasítását követően azt kell elfogadni, hogy a nagyobb 
átlag, szignifikáns eltérést mutat a kisebbhez képest és elfogadható a mintaátlagok alapján, hogy a várható érték nagyobb. A próba tehát egyoldali, jobb oldali ellenhipotézissel.

A nullhipotézis:

az ellenhipotézis:

$$
\mathrm{H}_{0}: \mu_{1}=\mu_{2}
$$

$$
\mathrm{H}_{1}: \mu_{1}>\mu_{2}
$$

ahol $\bar{x}_{1}>\bar{x}_{2}$. A statisztika próba során tehát a sorrend nem állandó a baloldalon minden esetben a nagyobb átlaggal rendelkező képzési forma szerepel. Az eredményeket a 2. táblázat mutatja.

A táblázat felépítése hasonló az 1. táblázatéhoz. A statisztikai próbák $\alpha=0,05$ szignifikanciszinten lettek elvégezve, vagyis a $p$ érték nagysága dönti el a nullhipotézis elfogadását vagy elvetését. Kékkel vannak jelölve azon esetek ahol a nullhipotézis lett elfogadva, vagyis a $p$ értéke meghaladta a 0,05 elöírt szignifikanciaszintet. Pirossal azon esetek ahol az ellenhipotézist kellet elfogadni. A teljesség kedvéért a táblázat tartalmazza a kritikus értékeket ( $\mathrm{t}$ érték) és próbastatisztikákat ( $\mathrm{t}$ kritikus egyszélü) is. Azokban az esetekben ahol a $p$ 0,05-nél kisebb ott a próbastatisztika meghaladja a kritikus értéket.

Az eredmények alapján megállapítható hogy a nyolc esetből hatszor lett elfogadva a nullhipotézis vagyis ezekben az esetekben kijelenthetö, hogy az egymást követő képzések során a hallgatók (honvéd tisztjelöltek) azonos szinten teljesítették a tantárgyakra vonatkozó követelményeket. Két esetben viszont az ellenhipotézist kellett elfogadni. Az első a Rendszerbentartás c. tantárgycsoport ahol kijelenthető, hogy a hadmérnök képzésben résztvevők magasabb szinten teljesítették az ide vonatkozó követelményeket, mint a gépészmérnök képzésben résztvevők. A második eset a Belsőégésü motorok a katonai logisztika-hadmérnök viszonylat, itt a katonai logisztika képzésben résztvevők teljesítették jobban a tantárgyakra vonatkozó követelményeket.

Fontos megjegyezni, hogy az említett két esetben a próbák nem magasabb tudásszintet jelentenek, hanem csak azt, hogy a két azonosított viszonylatban a csökkentett követelményrendszert a hallgatók (honvéd tisztjelöltek) könnyebben tudták teljesíteni. A maradék hat esetre kivetítve viszont ez azt jelenti, hogy a követelményszint teljesítésében nem történt változás. Az esetek többségében tehát, vagyis nyolc vizsgált viszonylatból hatszor a csökkentett követelményrendszert csak ugyanolyan szinten teljesítették a hallgatók.

Az egyes szakmai területek elsajátításának mélysége és színvonala az egymást követő képzési formák során tehát többnyire változatlan, ami esetünkben kisebb tudást jelent. 


\begin{tabular}{|c|c|c|c|c|}
\hline Jármúvek szerkezete & Gépészmérnök & Hadmérnök & Katonai Logisztika & Hadmérnök \\
\hline Átlag & 3,484848485 & 3,458333333 & 3,75 & 3,458333333 \\
\hline Variancia & 1,507575758 & 0,780797101 & 0,866666667 & 0,780797101 \\
\hline Megfigyelések & 33 & 24 & 16 & 24 \\
\hline Súlyozott variancia & 1,203650138 & & 0,814692982 & \\
\hline $\begin{array}{l}\text { Feltételezett átlagos } \\
\text { eltérés }\end{array}$ & 0 & & 0 & \\
\hline df & 55 & & 38 & \\
\hline t érték & 0,090088455 & & 1,001210573 & \\
\hline$P(T<=t)$ egyszélű & 0,464272101 & & 0,161529106 & \\
\hline t kritikus egyszélű & 1,673033965 & & 1,68595446 & \\
\hline Rendszerbentartás & Hadmérnök & Gépészmérnök & Hadmérnök & Katonai Logisztika \\
\hline Átlag & 4,444444444 & 4 & 4,444444444 & 4,4375 \\
\hline Variancia & 0,653968254 & 0,896551724 & 0,653968254 & 0,529166667 \\
\hline Megfigyelések & 36 & 30 & 36 & 16 \\
\hline $\begin{array}{l}\text { Súlyozott variancia } \\
\text { Feltételezett átlagos }\end{array}$ & 0,763888889 & & 0,616527778 & \\
\hline eltérés & 0 & & 0 & \\
\hline df & 64 & & 50 & \\
\hline t érték & 2,057037909 & & 0,029435455 & \\
\hline $\mathrm{P}(\mathrm{T}<=\mathrm{t})$ egyszélű & 0,021881469 & & 0,488317238 & \\
\hline t kritikus egyszélű & 1,669013025 & & 1,675905025 & \\
\hline Belsőégésú motorok & Gépészmérnök & Hadmérnök & Katonai Logisztika & Hadmérnök \\
\hline Átlag & 4 & 3,958333333 & 4,5625 & 3,958333333 \\
\hline Variancia & 1 & 1,346014493 & 0,2625 & 1,346014493 \\
\hline Megfigyelések & 21 & 24 & 16 & 24 \\
\hline $\begin{array}{l}\text { Súlyozott variancia } \\
\text { Feltételezett átlagos }\end{array}$ & 1,185077519 & & & \\
\hline eltérés & 0 & & 0 & \\
\hline df & 43 & & 34 & \\
\hline t érték & 0,128092703 & & 2,243970534 & \\
\hline $\mathrm{P}(\mathrm{T}<=\mathrm{t})$ egyszélü & 0,44933641 & & 0,015727619 & \\
\hline t kritikus egyszélű & 1,681070703 & & 1,690924255 & \\
\hline Vill. berendezések & Gépészmérnök & Hadmérnök & Katonai Logisztika & Hadmérnök \\
\hline Átlag & 4,083333333 & 3,833333333 & 4 & 3,833333333 \\
\hline Variancia & 1,174242424 & 1,060606061 & 0 & 1,060606061 \\
\hline Megfigyelések & 12 & 12 & 8 & 12 \\
\hline $\begin{array}{l}\text { Súlyozott variancia } \\
\text { Feltételezett átlagos }\end{array}$ & 1,117424242 & & & \\
\hline eltérés & 0 & & 0 & \\
\hline df & 22 & & 11 & \\
\hline t érték & 0,579304083 & & 0,560611911 & \\
\hline $\mathrm{P}(\mathrm{T}<=\mathrm{t})$ egyszélű & 0,284134546 & & 0,293149653 & \\
\hline t kritikus egyszélű & 1,717144374 & & 1,795884819 & \\
\hline
\end{tabular}

2. táblázat Kétmintás t-próba a várható értékre 


\section{KÖVETKEZTETÉSEK}

A korábbi kutatások alapján megállapítható, hogy az elmúlt másfél évtizedben három különbözö képzési formában lettek képezve a páncélos- és gépjármütechnika szakos hallgatók. Az egymást követő képzési formáknak a szakmai tartalma folyamatosan csökkent. A csökkenés mértéke legkisebb volt a belsőégésü motorok területén és legnagyobb a villamos berendezések területén.

Jelen tanulmány azt vizsgálta meg, hogy a változó pontosabban kifejezve csökkentett óraszámú és ezzel párhuzamosan csökkentett követelményeket a képzésekben résztvevők hogyan teljesítették.

A vizsgálat matematikai statisztika eszközeivel került elvégzésre. A kapott eredmények alapján kijelenthető, hogy az esetek többségében, vagyis a vizsgált nyolc viszonylatból hatszor nincs változás a követelmények teljesítésében. Vagyis többségében a csökkentett követelményeket ugyanazon a szinteken teljesítették a hallgatók, mint a megelöző képzés nehezebb követelményeit.

Két esetben volt megállapítható az osztályzatok átlagainak az emelkedése. Itt kijelenthető az átlagok emelkedése, ami jobb teljesítési szintre utal.

A vizsgálatok eredményeire fontos megállapítani, hogy a katonai logisztika alapképzési szak páncélos és gépjármütechnikai modulja esetében csak két évfolyam lett figyelembe véve. A szakon tanuló honvéd tisztjelöltek eredményességének és a tantárgyak elsajátításának a pontosabb meghatározásához a vizsgálatot két év múlva célszerü újra elvégezni.

A kutatási célként lehet, hogy a különböző képzési formában végzett fiatal tisztek hogyan válnak be a Magyar Honvédség alakulatainál. Ezt a tanulmányi eredmények és az egyes tárgyakra adott óramennyiség alapján viszont csak közvetve lehet megállapítani. A pontos mérést csak az alakulatoknál lehetne elvégezni egy olyan beválást vizsgáló rendszer segítségével, amely képes az objektív értékelésre, és ezen értékelések eredményeit lehetne jól felhasználni az adott képzés rendszer felülvizsgálatakor.

\section{FELHASZNÁLT IRODALOM}

[1] GYARMATI, J., VÉG, R. L., HEGEDÜS, E., GÁVAY, Gy. V.: A katonai felsőoktatás részvételének lehetöségei a kutatás-fejlesztési folyamatokban; Müszaki Katonai Közlöny XXVIII:(1) pp. 193-208. (2018).

[2] GÁVAY, Gy., GYARMATI, J., HEGEDÜS, E., VÉG, R. L.: A kutatás fejlesztés szerepe és hatása az oktatásra az NKE HHK Haditechnikai Tanszékén; Hadmérnök XII:(4) pp. 26-33. (2017).

[3] GYARMATI, J., GÁVAY, Gy., HAJDÚ, F., BIMBÓ, I.: Védelmi célú kutatások a Hadtudományi és Honvédtisztképzö Kar Haditechnikai Tanszékén, együttmüködésben a HM Védelemgazdasági Hivatallal; Hadtudomány 26:(3-4) pp. 89-99. (2016).

[4] HEGEDÜS, E.: Tudományos konferencia a haditechnikai kutatók és fejlesztök napján; Haditechnika 52:(3) pp. 43-45. (2018).

[5] GÁVAY, Gy.: A tervszerü fenntartási rendszer és az amerikai forrásból származó páncélos- és gépjármü-technikai eszközök karbantartási rendszere; Honvédségi Szemle 143:(4) pp. 85-92. (2015).

[6] GÁVAY, Gy., KENDE, Gy.: A hadfelszerelések életciklusával kapcsolatos fogalmak elemzése a fontosabb magyar és angol nyelvü kifejezések megfeleltetése; Hadmérnök 9: (3) pp. 267-273. (2014).

[7] SEBÖK, I., TAR Cs.: A katonai alapképzési szak fegyverzettechnikai moduljának felépitése a korábbi képzések tükrében, a szakmai tantárgyakra forditott óramennyiség szemszögéből; Bolyai Szemle 2016:(3) pp. 11-19. (2016). 
[8] GYARMATI, J., VÉG, R. L.: A katonai logisztika alapképzési szak páncélos- és gépjármü-technikai moduljának felépitése a korábbi képzések tükrében, szakmai szemszögböl; Hadmérnök XI:(2) pp. 1-7. (2016).

[9] SEBÖK, I.: A fegyver- és fegyverzettechnikai szakemberek oktatásának, képzésének vizsgálata az új elvek és irányok tükrében; Seregszemle, XVI. évfolyam, 1. szám, pp. 57$62,(2018)$. 